\title{
Effect of soil solarization combined with reduced doses of the fumigant metam sodium on management of some soil borne pathogens and root-knot nematode of pepper grown in greenhouse
}

\author{
Seral Yücel ${ }^{1 \star}$, Adem Özarslandan ${ }^{1}$ and Canan Can $^{2}$ \\ ${ }^{1}$ Biological Control Research Institute, 01220, Adana, Turkey. \\ ${ }^{2}$ University of Gaziantep, Faculty of Science and Letter, Biology Department, 27310, Gaziantep, Turkey. \\ Accepted 7 April, 2017
}

\begin{abstract}
This study aimed to define the effect of soil solarization and reduced dose of the fumigant metam sodium on managing of root-rot and wilt diseases, caused by Rhizoctonia solani and Fusarium solani, F. oxysporum, as well as the nematode Meloidogyne incognita of pepper (Capsicum annuum L.) grown in the greenhouses. The effect of metam sodium (MS) at 500, $750 \mathrm{~L} \mathrm{ha}^{-1}$ that accounts for 40 to $60 \%$ reduction of recommended dosage, on disease incidence, galling index and yield values was defined. Three different trials were conducted during 2014/2015 growing season in farmer's greenhouses. Pepper seedlings were planted in October, 2014 and plants were uprooted for evaluation in July, 2015. Disease incidence of wilt and root-rot diseases were 3.7 to $8.7,15.0$ to 17.5 and 32.5 to $36.2 \%$ in solarization combined with low dosage of fumigants, solarization alone and control plots, respectively. Disease incidence in plots where MS was applied at $1250 \mathrm{~L} \mathrm{ha}^{-1}$ was $1.2 \%$. Galling index caused by root-knot nematode was under 2 in treated plots, but in control plots of the three greenhouse experiments were $7.08,6.48$ and 7.29 , respectively. Yield value increased to the average of $56.6 \%$ in solarized plots compared to those of control plots. When the soil solarization was combined with low dosages of the fumigant MS (S+MS 500) and (S+MS 750), the increase in the yield values reached to the averages of 31.6 and $75.6 \%$, respectively.
\end{abstract}

Keywords: Pepper, metam sodium, solarization, soil borne pathogens, Meloidogyne incognita.

*Corresponding author. E-mail: seral.yucel@tarim.gov.tr, seralyucel@hotmail.com.

\section{INTRODUCTION}

In Turkey, pepper is cultivated under protected conditions and open fields reaching to about 79,000 ha, which produced about 2,5 million tons of fruits (TUIK, 2015). Climate of Mediterranean region of Turkey where extensive protected cultivation takes place is hot and humid during summer. Some soil borne pathogens, that is, Fusarium solani, F. oxysporum, Rhizoctonia solani and root-knot nematode (Meloidogyne incognita) significantly affect pepper production in this area. Phytophthora blight caused by Phytophthora capsici has been reported in field and greenhouse grown peppers in Turkey. However Fusarium wilt (Fusarium oxysporum) and root rot ( $F$. solani) have been reported to be the main soil borne pathogens after the drip irrigation system has become widespread in greenhouse grown peppers (Yücel et al., 2002). The annual yield loss caused by nematodes in the world reaches up to 12.3 to $20 \%$, and in vegetables to $80 \%$ (Sasser and Freckman, 1987). Meloidogyne arenaria (Neal, 1889) Chitwood, M. incognita (Kofoid and White, 1919) and M. javanica (Treub, 1885) Chitwood have been widespread and it is economically important rootknot nematode species in vegetable growing areas in Turkey (Söğüt and Elekçioğlu, 2000; Özarslandan and Elekçioğlu, 2010). Repeat planting of same crops in the greenhouses of Mediterranean region of Turkey causes biological soil pollution and economically important yield losses occur due to nematodes and soil-borne diseases unless effective fumigation methods are applied.

Soil solarization is widely used for soil disinfestations and has become very popular in controlling soil-borne pathogens and root-knot nematodes, since methyl bromide usage was banned in 2015. Studies have 
revealed that the efficiency of soil solarization depends on soil type, soil humidity, temperature, daylight length and density (Katan and Devay, 1991). Soil solarization alone has been reported to be ineffective against nematodes and soil-borne pathogens. Chellemi and Olson (1994), Chellemi and Mirusso, (2006) and Yılmaz et al. (2011) who reported that the formation of nematode galls takes 4 to 5 months following soil solarization in cucumber roots. The nematode population existing at soil depths may move towards the surface during vegetation period when the soil solarization alone is used (Mc Sorley et al., 1999). It is important to combine soil solarization with low dosage of soil fumigants in pepper to control root-knot nematodes, since pepper production time extends to 910 months that reduces the effect of solarization alone treatment as explained above. Registered dosage of metam sodium is $1250 \mathrm{~L} \mathrm{ha}^{-1}$, however when applied at reduced dosages in combination with soil solarization that is used extensively in the Mediterranean region, the cost is lowered in which environmental pollution is minimized.

Thus, this study was conducted to determine the combined effect of soil solarization and 60 to $40 \%$ reduced doses of metam sodium ( 500 to $750 \mathrm{~L} \mathrm{ha}^{-1}$ ) for controlling root-rot pathogens (Fusarium solani, F. oxysporum, Rhizoctonia solani) and root-knot nematode (Meloidogyne incognita) in pepper and determine the effects of treatments on yield parameters.

\section{MATERIALS AND METHODS}

\section{Experimental sites and fumigant}

Experiments were conducted in three farmer's greenhouses located in Kazanlı, Adanalıoglu-Mersin province of the Eastern Mediterranean region during the 2014-2015 growing season. The root-rot diseases and nematodes had been detected in the greenhouses and in which pepper was continuously grown in the previous seasons. The plant roots in the greenhouses were microscopically inspected before the experiments and gall containing roots were scaled with 0 to 10 galling index (Barker, 1986). The three experiment sites were chosen according to galling index scale 6 more and the root-rot incidences occurred between 20 and $30 \%$. The soil types were sandy loam, soil organic matter was 1.3 to $2.7 \%$ with $\mathrm{pH} 7.2$ to 7.9 . The type of plastic film used to cover the soil was low-density polyethylene film (PE) with a thickness of $0.03-\mathrm{mm}$. (Solplast, Spain). Commercial Sniper Fluid (500 g/L metam sodium) was obtained from Dogal Agricultural Company (Turkey).

\section{Treatments}

The soil solarization period began on July 21 to 27,2014 with clear plastic covering and metam sodium (MS) was applied on 4 to 7 August by drenching with $10 \mathrm{~L}$ of water per $\mathrm{m}^{2}$. Five treatments [soil solarization (S) alone, MS alone (1250 L ha $\left.{ }^{-1}\right)$, $\mathrm{S}+\mathrm{MS}$ at $500 \mathrm{~L} \mathrm{ha}^{-1} ; \mathrm{S}+\mathrm{MS}$ at $750 \mathrm{~L} \mathrm{ha}^{-1}$, untreated control] were arranged in a randomized complete block design with four replications per treatment. Each replicate plot consisted of raised beds with $10 \mathrm{~m}$ in length and $5 \mathrm{~m}$ wide. Solarization application continued for 7 to 8 weeks (Yucel et al., 2007a, b). The MS alone application was conducted according to manufacturer's instructions in which the fumigant was applied under the plastic covers, which was removed a week after the fumigation. On 12 to 28 October, pepper transplants (in 3 greenhouses, cultivar Safran $F_{1}$, Mert $F_{1}$, Maraton $F_{1}$, respectively) were transplanted into the center of the beds at $40 \mathrm{~cm}$ spacing, as 90 seedlings in each plot. Temperatures were recorded hourly by a data logger (Watchdog, Spectrum Technologies, Inc. IL, USA) at depths of 5, 15 and 25 $\mathrm{cm}$ in bare and solarized soil.

\section{Assessment of pest control in greenhouses}

Pepper plants were periodically examined during the vegetative period for soil-borne pathogens. About 9 months (on July 14 2015) after transplanting 20 plants from each plot were uprooted and examined for diseases. Plants exhibiting discoloration at root part, xylem and phloem tissues were recorded, and they were taken to laboratory for pathogen isolation.

Disease incidence was calculated using the formula: \%MG1 = $[(D C-D T) / D C] \times 100$, where $\% M G I=$ the percent effect, $D C=$ number of diseased plants in control, DT = number of diseased plants in treatments according to Abbott's formula (Abbott, 1925). Pathogenicity tests were conducted on fungi isolated from symptom exhibiting plants collected from experimental sites and 3 pepper varieties (Safran $F_{1}$, Mert $F_{1}$, Maraton $F_{1}$ ) were used (Singleton et al., 1993).

Second stage juvenile nematode population of pretreatment (Pi) and harvest period $(\mathrm{Pf})$ were taken from 0 to $30 \mathrm{~cm}$ soil depth. Soil nematodes were determined by using modified Baermann funnel method (Hooper, 1986) and population density was recorded by examining $100 \mathrm{~g}$ of soil under a light microscope. Root galling index was identified on 20 plants uprooted from each replicate using 0 to 10 scale, where $0=$ roots with no galls and $10=$ roots with maximal degree of galling, at the end of the growing season (Barker, 1986).

\section{Statistical analysis}

The \% effect of treatments on disease incidence and yield values was determined according to the Abbott formula. The data were analyzed using SPSS (SPSS Inc., Chicago, IL, USA) and the individual means were compared by the Duncan (multiple range) test and a confidence level of $95 \%(P<0.05)$ was considered as statistically significant.

\section{RESULTS}

\section{Soil temperature}

Maximum soil temperature at a $5 \mathrm{~cm}$ depth was $54^{\circ} \mathrm{C}$ and was $15^{\circ} \mathrm{C}$ higher in solarized soil than those of the untreated soil. Maximum soil temperatures at 15 and 25 $\mathrm{cm}$ depths were 46.5 and $43.3^{\circ} \mathrm{C}$ in solarized soils, respectively. The temperature differences between solarized and control plots at 15 and $25 \mathrm{~cm}$ soil depths were 10.3 and $7.5^{\circ} \mathrm{C}$, respectively (Figure 1).

\section{Disease control}

Fusarium solani, F. oxysporum and Rhizoctonia solani were re-isolated from the diseased exhibiting pepper plants of the experimental plots. The incidence of wilt and root-rot diseases of pepper was less in the reduced fumigant dosage applied plots when compared to those of soil solarization alone. When the effect of solarization combined with 40 to $60 \%$ reduced dosages of the MS was compared with effect of recommended dosage 


\section{Greenhouse 1}

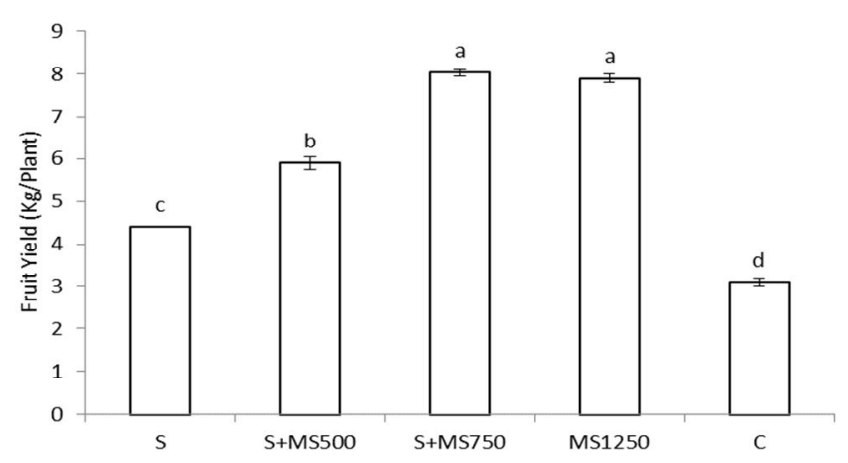

Greenhouse 2

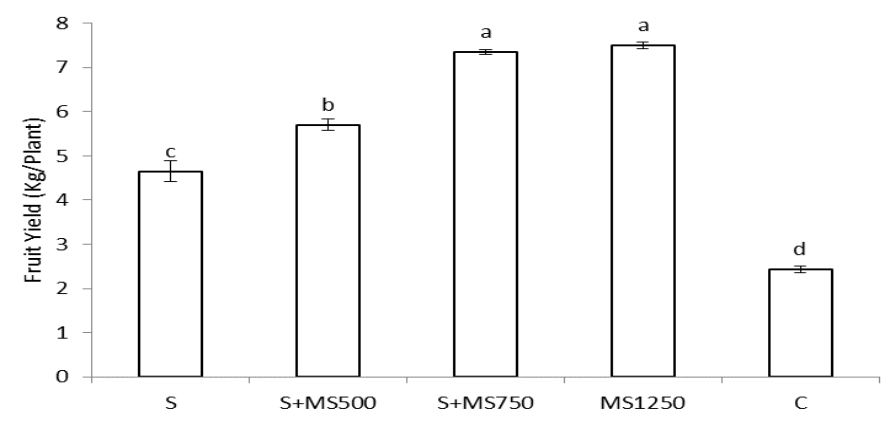

\section{Greenhouse 3}

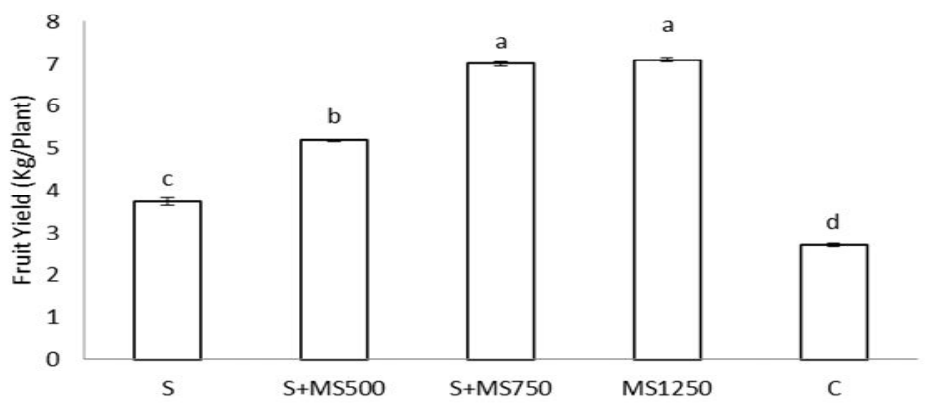

Figure 2. Effect of soil treatments on pepper yield in experimental greenhouses $\left(\mathrm{kg} \mathrm{plant}^{-1}\right)$. MS-500 to $750 \mathrm{~L} \mathrm{ha}^{-1}$, Letters next to numbers indicate different groups determined by Duncan's multiple comparison tests $(P<0.05)$.

(1250 L ha ${ }^{-1}$, statistically close parameters were recorded in greenhouses 1 and 2 (Table 1). Effect of reduced dosages of MS $\left(500,750 \mathrm{~L}^{-1}\right)$ in combination with solarization on disease incidence were 71.8 to 74.7 and 87.2 to $87.7 \%$ in greenhouse 1 and 2 , respectively. In greenhouse 3 , the effect on disease incidence of solarization alone, reduced and recommended dosages were 50 to $53.8,74.7$ to $86.6 \%$ and $96.4 \%$, respectively in which the difference was statistically important (Table 1).

\section{Nematode control}

Soil solarization combined with MS was used to manage the root-knot nematode in three farmer's greenhouses. No juvenile nematode and gall formation were detected in the experimental sites at the end of the growing season. The second stage root-knot nematode larva numbers in the three experimental sites were 380, 990 and 2625 in soil solarization alone and 2255,1540 and 3010 in control plots. The galling ratios 
Table 1. Average disease incidence values and effect of applications (\%) in 3 greenhouses

\begin{tabular}{lcccccc}
\hline Treatments & DI (\%) (G.1) $^{\mathbf{w}}$ & Efficacy (\%) $^{\text {DI (\%) (G.2) }}$ & Efficacy (\%) & DI (\%) (G. 3) & Efficacy (\%) \\
\hline Solarization $^{\mathbf{x}}$ & 15.0 & $53.8 \mathrm{c}^{\mathbf{z}}$ & 17.5 & $50.0 \mathrm{c}$ & 17.5 & $51.7 \mathrm{~d}$ \\
S+MS $^{\mathrm{y}} 500$ & 8.7 & $71.8 \mathrm{~b}$ & 8.7 & $74.7 \mathrm{~b}$ & 8.7 & $74.7 \mathrm{c}$ \\
S+MS 750 & 3.7 & $87.2 \mathrm{ab}$ & 5.0 & $87.7 \mathrm{ab}$ & 5.0 & $86.6 \mathrm{~b}$ \\
MS 1250 & 1.2 & $96.4 \mathrm{a}$ & 1.2 & $96.4 \mathrm{a}$ & 1.2 & $96.4 \mathrm{a}$ \\
Control & 32.5 & - & 35.0 & - & 36.2 & - \\
\hline
\end{tabular}

"Disease incidence ${ }^{w}$ Greenhouse $1{ }^{x}$ solarization ${ }^{y}$ metam sodium $\left(L\right.$ ha $\left.{ }^{-1}\right){ }^{z}$ Letters next to numbers indicate different groups determined by Duncan's multiple comparison tests $(P<0.05)$.

Table 2. Effect of reduced fumigant dosage on the density of $M$. incognita root galling of pepper

\begin{tabular}{|c|c|c|c|c|c|c|c|c|c|}
\hline \multirow{2}{*}{ Treatments } & \multicolumn{3}{|c|}{ Greenhouse1 } & \multicolumn{3}{|c|}{ Greenhouse2 } & \multicolumn{3}{|c|}{ Greenhouse3 } \\
\hline & $\mathrm{Pi}^{\mathrm{v}}$ & $\mathrm{Pf}^{\mathrm{w}}$ & Galling Index & $\mathbf{P i}$ & $\mathrm{Pf}$ & Galling Index & $\mathbf{P i}$ & $\mathrm{Pf}$ & Galling Index \\
\hline$S^{x}$ & $1360 \pm 165$ & $380 \pm 76 a$ & $4.88 \pm 0.12 b$ & $240 \pm 114$ & $990 \pm 178 a$ & $5.42 \pm 0.12 b$ & $960 \pm 236$ & $2625 \pm 445 b$ & $5.88 \pm 0.10 b$ \\
\hline S+MS 500 ha $^{-1}$ & $770 \pm 120$ & $0.0 \pm 0.0 a^{z}$ & $0.0 \pm 0.0 \mathrm{a}$ & $540 \pm 160$ & $0.0 \pm 0.0 \mathrm{a}$ & $0.0 \pm 0.0 \mathrm{a}$ & $1040 \pm 242$ & $0.0 \pm 0.0 \mathrm{a}$ & $0.0 \pm 0.0 \mathrm{a}$ \\
\hline S+MS 750 ha $^{-1}$ & $925 \pm 192$ & $0.0 \pm 0.0 \mathrm{a}$ & $0.0 \pm 0.0 a$ & $475 \pm 179$ & $0.0 \pm 0.0 \mathrm{a}$ & $0.0 \pm 0.0 \mathrm{a}$ & $800 \pm 434$ & $0.0 \pm 0.0 \mathrm{a}$ & $0.0 \pm 0.0 \mathrm{a}$ \\
\hline Control & $665 \pm 196$ & $2255 \pm 336 b$ & $7.08 \pm 0.10 c$ & $575 \pm 226$ & $1540 \pm 268 b$ & $6.48 \pm 0.09 c$ & $570 \pm 324$ & $3010 \pm 497 b$ & $7.28 \pm 0.10 c$ \\
\hline
\end{tabular}

${ }^{\mathrm{v}} \mathrm{Pi}$ : Initial population of $\mathrm{J} 2{ }^{\mathrm{w}} \mathrm{Pf}$ : Final population of $\mathrm{J} 2{ }^{\mathrm{x}}$ solarization ${ }^{\mathrm{y}}$ metam sodium ${ }^{\mathrm{z}}$ Letters next to numbers indicate different groups determined by Duncan's multiple comparison tests $(P<0.05)$.

were $4.88,5.42$ and 5.88 in solarization alone and $7.08,6.48$ and 7.28 in control plots (Table 2).

Soil solarization alone was not able to control rootknot nematode in the greenhouses, where pepper was planted continuously. However, a combination of soil solarization with soil fumigants effectively suppressed the nematode population during the pepper production period taking about 9 months.

\section{Yield}

Yield increase of 31.6 and $75.6 \%$ was observed in the plots, where solarization was combined with reduced dosage of fumigant as compared to the plots, where solarization alone was applied. There was no statistical difference in yield parameters between the two reduced dosages of fumigants. Averagely $56.6 \%$ of yield increase was determined in solarized plots when compared to those of control plots and the differences were statistically significant (Figure 2, Table 3).

\section{DISCUSSION}

Integrated pest management of soil-borne pathogens and nematodes requires effective applications of reduced pesticide dosages. In greenhouse vegetable production, soil solarization has been widely used in the Mediterranean region of Turkey for the last 20 years due to suitable climatic conditions. However, it has been reported that wilt and root-rot diseases caused by Fusarium spp. and Rhizoctonia solani and root knot nematode (Meloidogyne spp.) could not be managed by solarization alone (Chellemi and Olson, 1994). In the current study, we observed an increase in the efficiency of solarization combined with the reduced dosage of the fumigant metam sodium. We also observed that these applications could be effectively used in pest and disease control, which in turn reduce environmental pollution and time recommended for solarization. In addition, it was revealed that the reduced dosage of fumigant application combined with solarization was able to reduce disease incidence and nematode population with, increasing of yield values. The data also proved an effective suppression of pest and disease control 


\section{Control}

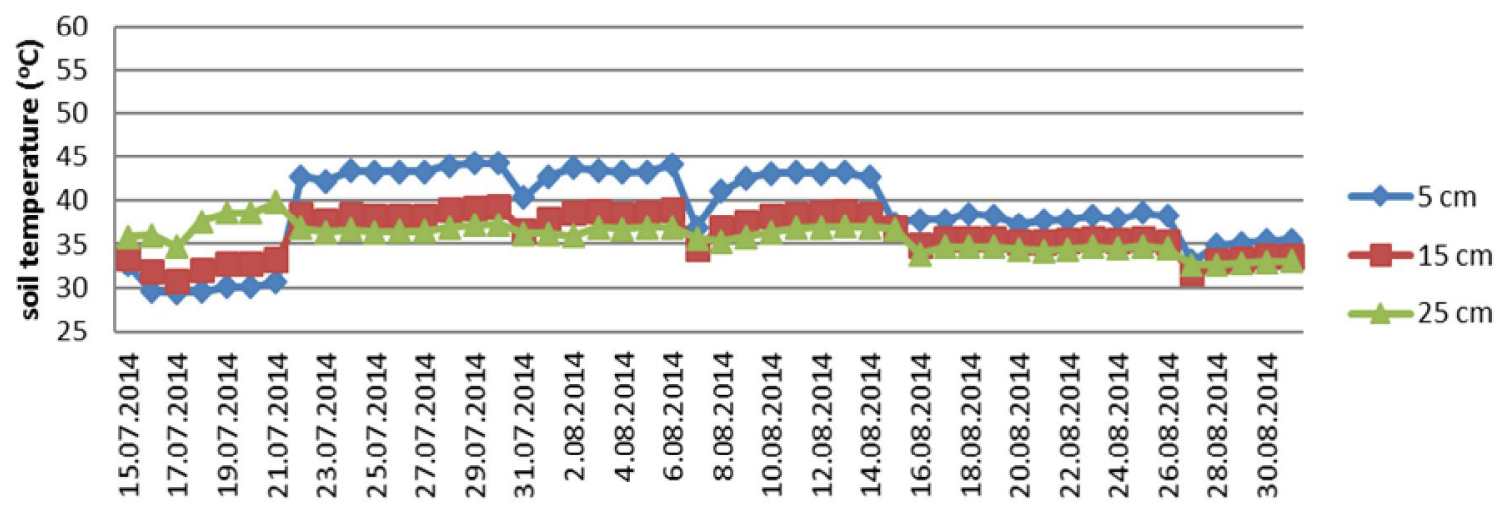

Solarization

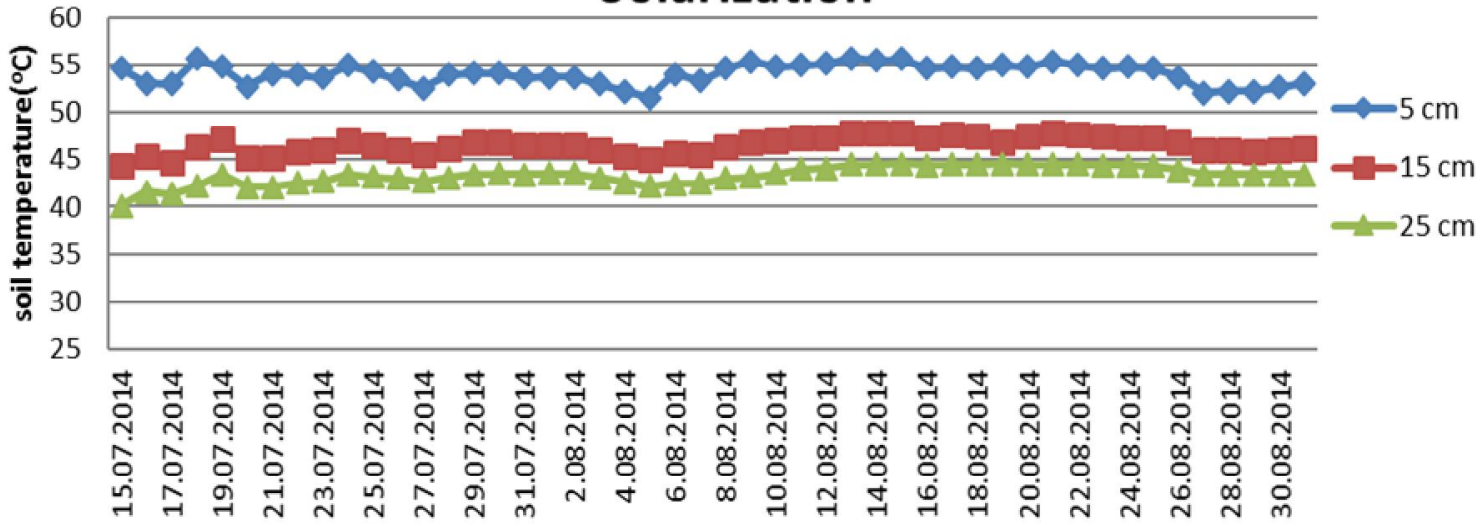

Figure 1. Soil temperatures at three soil depths under plastic films and bare soil during soil disinfection.

Table 3. Effect of soil treatments on pepper yield in experimental greenhouses $\left(\mathrm{kg} \mathrm{plant}^{-1}\right)$.

\begin{tabular}{lccc}
\hline Treatments & Greenhouse1-yield (kg plant $\left.^{-1}\right)$ & Greenhouse2 & Greenhouse3 \\
\hline Solarization (S) & $4.48 \pm 0.26 \mathrm{c}^{\mathrm{x}}$ & $4.66 \pm 0.23 \mathrm{c}$ & $3.72 \pm 0.09 \mathrm{c}$ \\
S+metam sodium (MS) 500 & $5.90 \pm 0.14 \mathrm{~b}$ & $5.76 \pm 0.13 \mathrm{~b}$ & $5.20 \pm 0.03 \mathrm{~b}$ \\
S+MS750 & $7.96 \pm 0.08 \mathrm{a}$ & $7.36 \pm 0.05 \mathrm{a}$ & $7.05 \pm 0.05 \mathrm{a}$ \\
S+MS1250 & $7.92 \pm 0.09 \mathrm{a}$ & $7.50 \pm 0.07 \mathrm{a}$ & $7.10 \pm 0.05 \mathrm{a}$ \\
Control & $3.06 \pm 0.09 \mathrm{~d}$ & $2.42 \pm 0.07 \mathrm{~d}$ & $2.70 \pm 0.03 \mathrm{~d}$ \\
\hline
\end{tabular}

${ }^{x}$ Letters next to numbers indicate different groups determined by Duncan's multiple comparison tests $(P<0.05)$.

during pepper production period in the three farmer's greenhouses (Tables 1 and 2).

Previous studies have demonstrated that control of soil-borne pathogens and plant parasitic nematodes could be improved when the reduced dosage of MS combined with solarization (Ben Yephet et al., 1988; Coelho et al., 1999; Sanogo, 2003; Yücel et al., 2007a). Such applications were reported to reduce detrimental effect of pesticides to environment (Eshel et al., 2000). Synergistic effect was observed when solarization was combined with low dosage of MS compared with those applications of each treatment alone. The effective control over soil-borne pathogens and root-knot nematodes was observed when registered dosage $\left(1250 \mathrm{~L} \mathrm{ha}^{-1}\right)$ was combined with reduced dosage of MS (40 to $60 \%$ ). Gamliel et al. (2000) reported the effectiveness of combined solarization and fumigants to control crown-rot of tomatoes ( $F$. oxysporum f.sp. radicis-lycopersici) and sudden wilt of melons (Monosporoascus cannonballus). The researchers observed that a significant reduction in the pathogen population when impermeable film was used for soil solarization combined with $1 / 3$ of recommended dosage of metam sodium and methyl bromide. In addition to pathogen control, increased plant vigor and growth were reported in solarized soils when compared 
to those of non-solarized soils (McSorley et al., 1999).

The maximum soil temperature was 1.2 to $5^{\circ} \mathrm{C}$ higher in present study when compared to those of previous studies conducted in the Mediterranean region of Turkey (Yucel et al., 2007a, b). This raise could be explained by soil structure difference and inconsistent climatic change for the last 10 years.

The experimental greenhouses chosen in this study had pepper plantations as monoculture for continuous years with high temperature and humidity as environmental factors. It is known that Fusarium spp. causing root-rot and wilt in greenhouse grown peppers are incited by humid and hot conditions. The disease incidence is suppressed in soils with better drainage and plants become less predisposed when planted on accordingly prepared planting beds (Yücel et al., 2002; Lamb and Rosskopf, 2003).

Soil population of plant parasitic nematodes at $0-20$ $\mathrm{cm}$ depth is controlled by 92 to $100 \%$ with solarization applications. But they may stay alive at $20 \mathrm{~cm}$ depth during solarization and move forward up to soil surface by time and cause economic damage on crop plants (McSorley et al., 1999). Similarly, soil solarization alone was reported to be effective for 4 to 5 months and that the galls were observed later on plant roots (Yılmaz et al., 2011). Galls formation on pepper plant roots were detected 4 months following solarization in the present study. We reported a nine month period of effective control of root-rot diseases and nematodes on pepper in planting beds previously prepared in the 3 greenhouses with solarization combined with MS at reduced dosages $\left(500,750 \mathrm{~L} \mathrm{ha}^{-1}\right)$ (Tables 1 and 2). Growth vigor and yield were increased in pepper plants with application of soil solarization compared with control plots (Table 3). Yucel et al. (2014) reported yield incerase in tomato greenhouses treated with same control measures.

Soil solarization alone is not effective in controlling soil-borne diseases and nematodes in greenhouses, where intensive cultivation is being conducted. Soil solarization should be combined with reduced dosage of fumigants to decrease the disease incidence and eventually to increase yield's quality and quantity in the Mediterranean climates. The cost is dropped by using reduced fumigant dosage, farmers profit is eventually increased and cordially the damage to environment is prevented. This study revealed that the application of soil solarization combination with $40 \%$ reduced dosage of MS had the same effect of recommended dosage of MS application. In addition $60 \%$ reduced dosage of MS was found to be acceptable for controlling soil borne pathogens and nematodes in less contaminated pepper greenhouses. It is assumed that the unsatisfactory results may be due to inefficient farming practices such as the application of soil solarization on dry soils, keeping diseased plant debris in greenhouses and deep processing (over $15 \mathrm{~cm}$ ) of soil.

\section{ACKNOWLEDGEMENTS}

The authors appreciate the financial support provided by Mersin Chamber of Commerce and Industry (Turkey).

\section{REFERENCES}

Abbott WS, 1925. A method of computing the effectiveness of an insecticide. J Econ Entomol, 18: 265-267.

Barker KR, Townshend JL, Bird GW, Thomason IJ, Dickson DW 1986. Determining nematode population responses to control agents. In: Hickey KD editor. Methods for Evaluating Pesticides for control of Plant Pathogens, 1st Ed, St. Paul, MN, USA: APS Press, pp 283-296.

Ben Yephet $Y$, Melero DE, DeVay, JM, 1988. Interaction of soil solarization and metham-sodium in the destruction of Verticillium dahilae and Fusarium oxysporum f.sp. vasinfectum. Crop Protect, 7: 327-331.

Chellemi DO, Mirusso J, 2006. Optimizing soil disinfestation procedures for fresh market tomato and pepper production. Plant Dis, 90: 668-674.

Chellemi DOS, Olson M, 1994. Effect of soil solarization and fumigation on survival of soil-borne pathogens of tomato in Northern Florida. Plant Dis, 78(2): 1167-1172.

Coelho L, Chellemi DO, Mitchell DJ, 1999. Efficacy of solarization and cabbage amendment for the control of Phytophthora spp. in North Florida. Plant Dis, 83: 293-299.

Eshel D, Gamliel A, Grinstein A, Di Primo P, Katan J, 2000. Combined soil treatments and sequence of application in improving the control of soil-borne pathogens. Phytopathology, 90: 751-757.

Gamliel A, Grinstein A, Zilberg V, Beniches M, Ocko O, Katan J, 2000. Control of soil-borne diseases by combining soil solarization and fumigants. Acta Hortic, 532: 157-164.

Hooper DJ, 1986. Handling, Fixing, Staining and Mounting Nematodes. In: Southey JF, editor. Laboratory Methods for Work with Plant and Soil Nematodes. $1^{\text {st }}$ ed. London, UK: Her Majesty's Stationery Office, pp. 59-80.

Katan J, Devay J, 1991. Soil Solarization. $1^{\text {st }}$ ed. New York, USA: CRS Press Inc.

Lamb EM, Rosskopf EN, 2003. Fusarium Stem Rot. In: Pernezny K, Roberts PD, Murphy JF, Goldberg NP, editors. 1st ed Compendium of Pepper Diseases, St. Paul, MN, USA: APS Press, pp 13-14.

McSorley R, Ozores-Hampton M, Stansly PA, Conner JM, 1999 Nematode management, soil fertility, and yield in organic vegetable production. Nematropica, 29: 205-213.

Özarslandan A, Elekçioğlu IH, 2010. Türkiye'nin farklı alanlarından alınan kök ur nematodu türlerinin (Meloidogyne spp.) (Nemata: Meloidogynidae) moleküler ve morfolojik tanıma ile belirlenmesi. Türkiye Entomoloji Dergisi, 34(3): 323-335.

Sanogo S, 2003. Chile pepper and the threat of wilt diseases. Plant Health Progress. doi: 10.1094/PHP-2003-0430-01-RV.

Sasser JN, Freckman DW, 1987. A World Perspective on Nematology: The Role of the Society. In: Veech JA, Dickson DW, editors. Vistas on Nematology. Hyattsville, Maryland, USA: Society of Nematology, 7-14.

Singleton LL, Mihail JD, Rush CM, 1993. Methods for Research on Soilborne Phytopathogenic Fungi. 1st Ed. St. Paul, MN, USA: APS Press.

Söğüt MA, Elekçioğlu IH, 2000. Akdeniz Bölgesi'nde sebze alanlarında bulunan Meloidogyne Goeldi, 1892 (Nemata: Heteroderidae) türlerinin ırklarının belirlenmesi. Türkiye Entomoloji Dergisi, 24(1): 33-40.

TUIK, 2015. Turkish Statistical Institute, Ankara, Turkey.

Yılmaz S, Ceelik I, Zengin S, 2011. Combining effects of soil solarization and grafting on plant yield and soil-borne pathogens in cucumber. Int J Plant Prod, 5(1): 1735-8043.

Yücel S, Elekçioğlu İH, Can C, Söğüt MA, Özarslandan A, 2007a. Alternative treatments to Methyl Bromide in the Eastern Mediterranean region of Turkey. Turk J Agric, 31:47-53.

Yücel $S$, Elekçioğlu İH, Uludağ A, Can C, Gözel U, Söğüt MA, Özarslandan A, Aksoy E, 2002. The second year results of Methyl Bromide alternatives in in the Eastern Mediterranean part of Turkey. Annual International Research Conference on Methyl Bromide Alternatives and Emissions Reductions, Florida, USA. pp. 10-1/10-4.

Yücel S, Özarslandan A, Can C, Gunactı H, 2014. Case Studies and Implications of Chemical and Non-chemical Soil Disinfection 
Methods in Turkey. Proc. $8^{\text {th }}$ on Chemical and Non-Chemical Soil and Substrate Disinfestation. Acta Hort., 1044: 295-300.

Yücel S, Özarslandan A, Çolak A, Ay T, Can C, 2007b. Effect of solarization and fumigant applications on soil-borne pathogens and root-knot nematodes in green house grown tomato in Turkey. Phytoparasitica, 35(5): 450-456.
Citation: Yücel S, Özarslandan A, Can C, 2017. Effect of soil solarization combined with reduced doses of the fumigant metam sodium on management of some soil borne pathogens and rootknot nematode of pepper grown in greenhouse. Net J Agric Sci, 5(2): 31-37. 